\title{
Why do People have the Saving Behavior? A Reference from Sylhet City
}

\author{
Mohammad Kamrul Ahsan \\ Senior Lecturer, Department of Business Administration, Metropolitan University, Sylhet, BANGLADESH \\ Corresponding Contact: \\ Email: ahsan404243@gmail.com
}

\begin{abstract}
Saving is the difference in individual's disposable earnings and its consumption. Saving is the human behavior. The main aim of this paper is to identify out why people have the saving behavior. A structured questionnaire was used to collect primary data from 232 people from the different parts of Sylhet city in Bangladesh. Several statistical tools, i.e., Descriptive Statistics, Factors Analysis and Multiple Regression Analysis, have been conducted to find out core cause of the human saving behavior. The researcher has found five core factors for having this human saving behavior, i.e., 1. Have a facility in old age, 2 . Have enough social security, 3. Purchase land/house, 4.Dependent persons, and 5. Good profit/interest.
\end{abstract}

Keywords: Save, factors, Saving Behavior

$12 / 20 / 2016$

Source of Support: Nil, No Conflict of Interest: Declared

How to Cite: Ahsan M.K. 2016. Why do People have the Saving Behavior? A Reference from Sylhet City $A B C$ Journal of Advanced Research, 5, 77-90.

This article is is licensed under a Creative Commons Attribution-NonCommercial 4.0 International License.

Attribution-NonCommercial (CC BY-NC) license lets others remix, tweak, and build upon work non-commercially, and

although the new works must also acknowledge \& be non-commercial.

\section{INTRODUCTION}

Saving is the habit of human due to the fact anybody is conscious touching his future. To stand out of danger between futures, those perform make savings. They spend these savings in the rainy day. There are half variables which affect in accordance by saving. Saving is the concerning the variables because of monetary growth concerning any country. Saving is as regards a profit to that amount is not fed on by using at once shopping for fit-out or purposes (Prinsloo, 2000; Manyama, 2007).

According to conformity with the life-cycle speculation is so much the people shop mostly in with finance retirement. The evidence of requests suggests to that amount incomplete saving is instituted to provide inheritances for children. There is also increasing the amount of evidence after support the consider so much partial recovery is precautionary, undertaken by a guard in opposition to rainy days. In ignoble phrases, savings are aged as a buffer-stock, introduced in imitation of when instances are proper into order in imitation of preserve destruction. One quantity of evidence because this other motive is so historic human beings not often in reality dis-save, the older she are, the more they worry about after offer sizeable payments because of clinical seriousness or therefore, the greater reluctant he are to consume (Abid \& Afridi, 2010). 


\section{Research Questions}

- What are the causes of having human saving behavior?

- Is there any significant relationship between the causes of human saving behavior and saving propensity?

\section{Research Objectives}

- To find out some important causes that affect human saving behavior.

- To show the relationship between the causes of human saving behavior and saving propensity.

\section{Research Hypothesis}

$\mathrm{H}_{0}$ : There is no significant relationship between the causes of human saving behavior and saving propensity.

$\mathrm{H}_{1}$ : There have significant relationships between the causes of human saving behavior and saving propensity.

\section{Research Methodology}

In this study, the researcher has used a descriptive research design and a quantitative research approach.

\section{Population}

All the adult people in the Sylhet city have addressed in this study.

\section{Sampling}

The sampling population of this study includes 232 people from different parts of the Sylhet City. The researchers have provided 300 questionnaires to the people but got only 232 questionnaires (77.33\%) filled up. For this reason, the sample size is 411 . This study followed the random sampling method representing the population.

\section{Study Period}

This study is based on primary data. These primary data have been collected from Sylhet City during November 2015 to April 2016.

\section{Tools of Data Collection}

The data is collected by using a structured questionnaire from the 232 depositors and of them males are $180(77.58 \%)$, and females are $52(22.41 \%)$ in numbers. The questionnaire has two parts, i.e., Part 1 has demographic information, and part 2 has several causes of saving. To find out the causes of human saving behavior, the researcher has considered fifteen factors as independent factors and only one factor as a dependent factor that is saving propensity. These fifteen factors are rated by Five Points Likert Scale. These are 1=Strongly Dissatisfied, 2=Dissatisfied, 3=Average, 4=Satisfied, 5=Strongly Satisfied. To verify the collected data relating to these factors several statistical tools (Descriptive Analysis, Factors Analysis, and Multiple Regression Analysis) have been conducted. The researcher has used SPSS 11.5 software to analyze these.

The researcher has used various books, journals, and periodicals as the vital source of secondary data. 


\section{LIMITATIONS}

- These data have collected from Sylhet city. So, it cannot represent throughout Bangladesh.

- Different people have different observations, different choices, and different saving behavior.

- Some people hesitate to provide information because they are worried about tax related issues.

- Female respondents are fewer than male respondents. So, there is a lack of females' opinions.

\section{Literature ReVIEW ANd CONCEPTUAL FrameWork}

There are a vast number of empirical studies on saving determinants. Since they are devoted to various countries and periods, they often lead to different findings. In this section, only a selection of the related literature is presented. Its aim is to show how the variables we discussed earlier can be tested empirically and what conclusions are often obtained (Kolasa \& Liberda, 2014).

Saving is earnings not spent, and then deferred consumption. Methods regarding recovery consist of placing money aside in, because of example, a credit account, a pension account, an investment fund, yet as much cash (Dell'Amore, 1983).

Propensity means a tendency to engage in a specified behavior. So, propensity to save means to engage saving behavior. Whenever we are discussing propensity to save, it means the marginal propensity to save. Marginal propensity to save (MPS) refers to increase in savings those results from an increase in the income (Oxford Dictionaries 2016; Wikipedia 2016).

My Money Coach (2016) explained ten reasons why you should save money, i.e., 1. Become Financially Independent, 2 . Save $50 \%$ on Everything You Buy $+24 \%$ on Groceries, 3. Buy a Home, 4. Buy a Car, 5. Get Out of Debt, 6. Annual Expenses, 7. Unforeseen Expenses, 8. Emergencies, 9. You Could Lose Your Job or Get Hurt, and 10. To Have a Good Life.

The Balance (2016) provided seven reasons of savings, i.e., 1. Save for Emergency Funds, 2. Save for Retirement, 3. Save for a Down Payment for a House, 4. Save for Vacations and Other Luxury Items, 5. Save for a New Car, 6. Save for Sinking Funds, and 7. Your Education.

Discover (2016) gave three reasons to save more money, i.e., 1) Reduced Job Security, 2) Fewer Benefits for Workers, and 3) Rising Healthcare Costs.

Piggypot (2016) provided the top three reasons to save money, i.e., 1. Savings goals, 2. Unexpected costs, and 3. Opportunities come around.

The Extra Income Project (2016) provided seven best reasons you should save money, i.e., 1. Save money for an emergency, 2. Save money for bad times, 3. Save money for College, 4. Save money for a house, 5. Save money for travel, 6. Save money for financial freedom, and 7. Save money for retirement.

Horioka \& Terada-Hagiwara (2012) argued that the determinants of savings in Asia are: the old dependency ratio, income levels, and the level of financial sector development. 
Bendig et al. (2009) analyzed remittances, risk exposure, shock experience as key determinants of savings. Empirical findings suggested that remittances were seemed to have a significant direct effect on saving.

Fraczek (2011) told that the level of savings depends on various factors such as income, interest rates, fiscal factors, demographics factors as well as psychological, cultural, and social factors.

\section{Conceptual Framework}

1. Have enough credit access

2. Have no liabilities to pay

3. Don't have any provision for pension scheme

4. Have to purchase land/house

5. Have a chance for future unemployment

6. Have to buy durable goods

7. Children education/Dependent education

8. Have remittance access

9. Have some suitable saving scheme

10. Have some dependent persons

11. Want to be rich man/To have social status

12. To get a good profit/Interest

13. To have enough social security

14. To have facility in old age

15. To study/travel in future

Independent Variables

Saving

Propensity

\section{ariable}

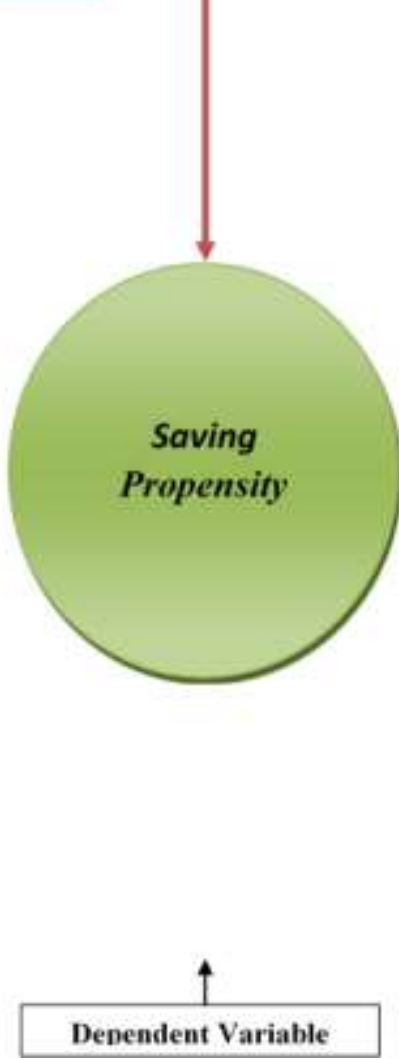

Source: Author's Compilation, 2016 
ANALYSIS AND FINDINGS

Demographic Information

Table No. 1: Profile of the Respondents

\begin{tabular}{|c|c|c|c|}
\hline S. No. & Demographic Profile & Number & Percentage \\
\hline \multirow[t]{4}{*}{1} & Gender & & \\
\hline & Male & 180 & 77.6 \\
\hline & Female & 52 & 22.4 \\
\hline & Total & 232 & 100 \\
\hline \multirow[t]{6}{*}{2} & Age Groups & & \\
\hline & 20 to 30 & 61 & 26.3 \\
\hline & 31 to 40 & 106 & 45.7 \\
\hline & 41 to 50 & 49 & 31.1 \\
\hline & 51 and above & 16 & 6.9 \\
\hline & Total & 232 & 100 \\
\hline \multirow[t]{4}{*}{3} & Employment Status & & \\
\hline & Employed & 139 & 59.9 \\
\hline & Unemployed & 93 & 40.1 \\
\hline & Total & 232 & 100 \\
\hline \multirow[t]{6}{*}{4} & Profession & & \\
\hline & Employee & 90 & 38.8 \\
\hline & Businessman & 55 & 23.7 \\
\hline & Student & 47 & 20.3 \\
\hline & Others & 40 & 17.2 \\
\hline & Total & 232 & 100 \\
\hline \multirow[t]{6}{*}{5} & Level of Education & & \\
\hline & Undergraduate & 61 & 26.3 \\
\hline & Graduate & 93 & 40.1 \\
\hline & Postgraduate & 66 & 28.4 \\
\hline & Others & 12 & 5.2 \\
\hline & Total & 232 & 100 \\
\hline
\end{tabular}

Source: Author's Calculation (Based on Field Survey, 2016)

From the above table, the analyst has found that guys are more than females in number. Most of them are in the group of 31 to 40 age, employed, and graduate.

\section{Factors Influencing to Save}

More mean, and less standard deviation indicate more important factors (Rahman, 2014) relating to the propensity to save. By the table no.2, it is clear that 'to have enough social security" is the most important factor to the propensity to save (Mean 3.78, and SD 0.91). Then takes place for 'children education' (Mean 3.72, and SD 1.15), and 'to get good interest' $(3.71$, and 0.81$)$. To be a rich man is in the $4^{\text {th }}$ place for a cause of human saving. 
Table No. 2: Descriptive Statistics

\begin{tabular}{|r|l|r|c|}
\hline \multicolumn{3}{|c|}{ Descriptive Statistics } \\
\hline & \multicolumn{2}{|c|}{ Mean } & Std. Deviation \\
\hline 1 & To have enough social security & 3.7802 & 0.91592 \\
\hline 2 & I save because of children education/dependent education & 3.7241 & 1.15909 \\
\hline 3 & To get a good profit/interest & 3.7155 & 0.81444 \\
\hline 4 & I want to be rich man & 3.6940 & 0.86107 \\
\hline 5 & I have to study/travel in future & 3.6767 & 1.01665 \\
\hline 7 & To have facility in old age & 3.6681 & 1.13092 \\
\hline 8 & I have some dependent persons & 3.6422 & 1.11911 \\
\hline 9 & I have to buy durable goods & 3.6078 & 1.08772 \\
\hline 10 & I have no liabilities to pa & 3.5560 & 1.25058 \\
\hline 11 & I don't have any provision for pension scheme & 3.2284 & 1.12217 \\
\hline 12 & I have remittance access & 3.1638 & 1.12772 \\
\hline 13 & I have suitable saving scheme & 3.1466 & 1.18252 \\
\hline 14 & I have to enough credit access & 2.9181 & 1.0776 \\
\hline 15 & I have a chance for future unemployment & 2.8664 & 1.31731 \\
\hline & Valid N (list wise) & 232 & \\
\hline
\end{tabular}

Source: Author's Calculation (Based on Field Survey, 2016)

\section{Reliability and Validity Test}

The right information will demonstrate the genuine outcomes. So, Cronbach alpha shows the validity and reliability of data set.

Table No. 3: Reliability Test

\begin{tabular}{|c|c|}
\hline Reliability Analysis - Sc & lpha) \\
\hline $\begin{array}{l}\text { Reliability Coefficients } \\
\mathrm{N} \text { of Cases }=232.0\end{array}$ & $\mathrm{~N}$ of Items $=15$ \\
\hline Alpha $=0.7716$ & \\
\hline
\end{tabular}

Source: Author's Calculation (Based on Field Survey, 2016)

Here for 15 items, Cronbach alpha is 0.7716 which is greater than 0.70 and less than 0.90 (Cortina, 1993). That implies the analyst has utilized exceptionally dependable information for an investigation.

\section{Sample Adequacy and Sphericity Test}

The accompanying table no. 4 gives data about specimen adequacy list KMO by KaiserMeyer-Olkin, which looks at the sizes of the watched connection coefficients to the sizes of the fractional relationship coefficients for the entirety of examination factors is $(0.722)$ $77.2 \%$, and it is solid since it beats $(0.70) 70 \%$ by a long shot (cut-off over 0.50 ) (Yong \& Pearce, 2013) . Also, supposition test of sphericity by the Bartlett test $\left(\mathrm{H}_{0}\right.$ : There is no significant relationship between the causes of human saving behavior and saving propensity) is rejected on a level of statistical significance $\mathrm{p}<0.0005$ for Approx. ChiSquare $=844.302$. Consequently, the coefficients are not all zero, so the second acceptance of factor analysis is satisfactory (Anastasiadou, 2011). 
Table No. 4: Sample Adequacy and Sphericity Test

KMO and Bartlett's Test

\begin{tabular}{|l|l|r|}
\hline Kaiser-Meyer-Olkin Measure of Sampling Adequacy. & 0.722 \\
\hline Bartlett's Test of Sphericity & Approx. Chi-Square & 844.302 \\
\hline & df & 105 \\
\hline & Sig. & .000 \\
\hline
\end{tabular}

Source: Author's Calculation (Based on Field Survey, 2016)

\section{The Scree Plot Graph}

The Scree plot demonstrates the graphical representation of eigenvalues and advisers for deciding the basic factorial pivot. The foundation of eigenvalue or trademark root (Eigenvalue) $\geq 1$ was utilized for characterizing the quantity of the variables (Kaiser, 1960).

Figure 1: Scree Plot Graph

\section{Scree Plot}

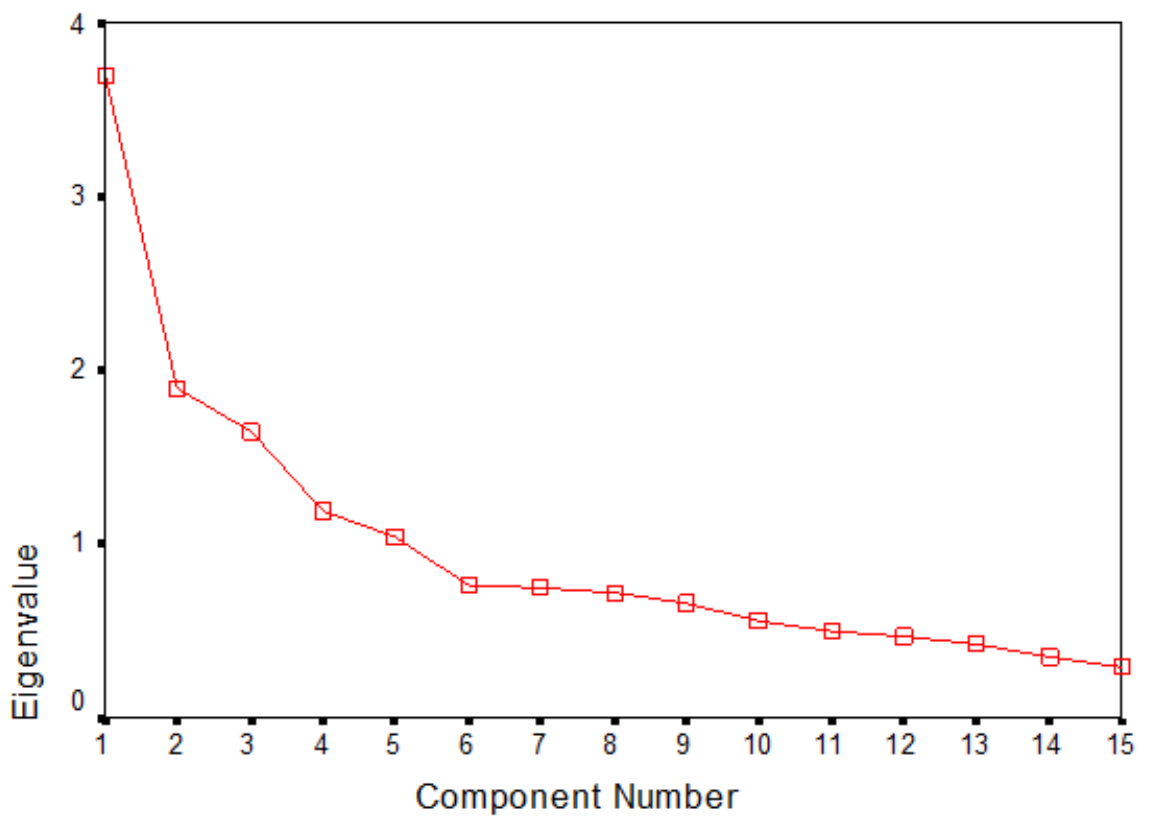

Source: Author's Calculation (Based on Field Survey, 2016)

The above figure (figure No. 1) shows that only five factors consider because these factors have eigenvalue over one, i.e., $3.691,1.896,1.654,1.198$, and 1.043 for the $1^{\text {st }}, 2^{\text {nd }}, 3^{\text {rd }}, 4^{\text {th }}$, and $5^{\text {th }}$ factor respectively and (Table No. 5) decide whether they interpret data in a satisfactory way. 
Table No. 5: Eigen values and Variance

\begin{tabular}{|c|c|c|c|c|c|c|c|c|c|}
\hline \multicolumn{8}{|c|}{$\begin{array}{c}\text { Tnitial Eigen } \\
\text { values }\end{array}$} & \multicolumn{3}{c|}{$\begin{array}{c}\text { Extraction Sums of } \\
\text { Squared Loadings }\end{array}$} & \multicolumn{3}{|c|}{$\begin{array}{c}\text { Rotation Sums of } \\
\text { Squared Loadings }\end{array}$} \\
\hline $\begin{array}{c}\text { Compo } \\
\text { nent }\end{array}$ & Total & $\begin{array}{c}\text { \% of } \\
\text { Variance }\end{array}$ & $\begin{array}{c}\text { Cumula } \\
\text { tive } \%\end{array}$ & Total & $\begin{array}{c}\% \text { of } \\
\text { Variance }\end{array}$ & $\begin{array}{c}\text { Cumula } \\
\text { tive } \%\end{array}$ & Total & $\begin{array}{c}\% \text { of } \\
\text { Variance }\end{array}$ & $\begin{array}{c}\text { Cumula } \\
\text { tive } \%\end{array}$ \\
\hline 1 & 3.691 & 24.605 & 24.605 & 3.691 & 24.605 & 24.605 & 2.165 & 14.431 & 14.431 \\
2 & 1.896 & 12.643 & 37.248 & 1.896 & 12.643 & 37.248 & 2.017 & 13.449 & 27.880 \\
3 & 1.654 & 11.024 & 48.272 & 1.654 & 11.024 & 48.272 & 1.983 & 13.220 & 41.101 \\
4 & 1.198 & 7.985 & 56.257 & 1.198 & 7.985 & 56.257 & 1.732 & 11.549 & 52.650 \\
5 & 1.043 & 6.951 & 63.208 & 1.043 & 6.951 & 63.208 & 1.584 & 10.558 & 63.208 \\
6 & 0.772 & 5.145 & 68.353 & & & & & & \\
7 & 0.756 & 5.037 & 73.390 & & & & & & \\
8 & 0.723 & 4.817 & 78.208 & & & & & & \\
9 & 0.666 & 4.440 & 82.648 & & & & & & \\
10 & 0.558 & 3.718 & 86.366 & & & & & & \\
11 & 0.501 & 3.341 & 89.707 & & & & & & \\
12 & 0.476 & 3.175 & 92.882 & & & & & & \\
13 & 0.421 & 2.806 & 95.688 & & & & & & \\
14 & 0.356 & 2.376 & 98.063 & & & & & & \\
15 & 0.291 & 1.937 & 100.000 & & & & & & \\
\hline
\end{tabular}

Extraction Method: Principal Component Analysis.

Source: Author's Calculation (Based on Field Survey, 2016)

The table No. 5 displays the Eigenvalue regarding the percentage of variance explained. So, factor 1 explains $24.605 \%$ of total variance. It is clear that the first few factors explain relatively large amounts of variance whereas subsequent factors explain only small amounts of variance. SPSS extracts all factors with eigenvalues greater than 1, which leaves with five factors. These five factors explain $63.208 \%$ of total variance.

Table No. 6: Communalities

\begin{tabular}{|r|l|c|c|}
\hline \multicolumn{2}{|c|}{ Communalities } & \multicolumn{1}{l|}{} \\
\hline & Factors & Initial & Extraction \\
\hline 1 & I have to enough credit access & 1.000 & 0.624 \\
\hline 2 & I have no liabilities to pa & 1.000 & 0.703 \\
\hline 3 & I don't have any provision for pension scheme & 1.000 & 0.555 \\
\hline 4 & I have to purchase land/hours & 1.000 & 0.701 \\
\hline 5 & I have a chance for future unemployment & 1.000 & 0.671 \\
\hline 6 & I have to buy durable goods & 1.000 & 0.659 \\
\hline 7 & I save because of children education/dependent education & 1.000 & 0.681 \\
\hline 8 & I have remittance access & 1.000 & 0.577 \\
\hline 9 & I have suitable saving scheme & 1.000 & 0.756 \\
\hline 10 & I have some dependent persons & 1.000 & 0.646 \\
\hline 11 & I want to be rich man & 1.000 & 0.505 \\
\hline 12 & To get a good profit/interest & 1.000 & 0.615 \\
\hline 13 & To have enough social security & 1.000 & 0.684 \\
\hline 14 & To have facility in old age & 1.000 & 0.600 \\
\hline 15 & I have to study/travel in future & 1.000 & 0.505 \\
\hline
\end{tabular}

Extraction Method: Principal Component Analysis

Source: Author's Calculation (Based on Field Survey, 2016) 
The communalities in the Extraction column reflect the common variance in the data structure or the proportion of variance explained by the underlying factors. i.e., $62.5 \%$ of the variance associated with question 1 (Factor 1) is common or shared, variance. The common communality table shows that every question has the extraction esteem more than 0.50 which speak to the agreeable nature of the estimations from the model of 5 variables (Anastasiadou, 2011).

Table No. 7: Rotated Component Matrix

\begin{tabular}{|l|c|c|c|c|c|}
\hline \multicolumn{5}{|c|}{ Rotated Component Matrix(a) } \\
\hline \multirow{2}{*}{ Questions } & \multicolumn{5}{|c|}{ Component/Factors } \\
\hline & F 1 & F 2 & F 3 & F 4 & F 5 \\
\hline To get a good profit/interest & 0.721 & & & & \\
\hline To have enough social security & 0.718 & & & & \\
\hline I want to be rich man & 0.630 & & & & \\
\hline I have to study/travel in future & 0.539 & & & & \\
\hline I have some dependent persons & 0.519 & & & & \\
\hline $\begin{array}{l}\text { I save because of children education/ } \\
\text { dependent education }\end{array}$ & & 0.796 & & & \\
\hline I have to buy durable goods & & 0.788 & & & \\
\hline I have to purchase land/house & & 0.590 & & & \\
\hline I have no liabilities to pay & & & 0.821 & & \\
\hline I have to enough credit access & & & 0.746 & & \\
\hline I don't have any provision for pension scheme & & & 0.642 & & \\
\hline I have a chance for future unemployment & & & & 0.792 & \\
\hline To have facility in old age & & & & 0.691 & \\
\hline I have suitable saving scheme & & & & & 0.814 \\
\hline I have remittance access & & & & & 0.661 \\
\hline
\end{tabular}

Extraction Method: Principal Component Analysis.

Rotation Method: Varimax with Kaiser Normalization.

a. Rotation converged in 7 iterations.

Source: Author's Calculation (Based on Field Survey, 2016)

By the use of SPSS Principle Component Factor Analysis, it is clear that total fifteen factors can be divided five groups of new factors.

Factor 1 named "Social security with plan" contains following variables:

1 To get a good profit/interest

0.721

2 To have enough social security 0.718

3 I want to be rich man $\quad 0.630$

4 I have to study/travel in future $\quad 0.539$

5 I have some dependent persons $\quad 0.519$

Eigen values $\quad 3.691$

Variance Explained $24.605 \%$

Factor 1 contains 5 variables with high loading $(0.721,0.718,0.630,0.539$, and 0.519), with Eigen values 3.691 which explained $24.605 \%$ of total dispersion. 
Factor 2 named "Purchase and Children Education" contains following variables:

6 I save because of children education/dependent education $\quad 0.796$

7 I have to buy durable goods 0.788

8 I have to purchase land/house $\quad 0.590$

Eigen values $\quad 1.896$

Variance Explained $\quad 12.643 \%$

Factor 2 contains $6^{\text {th }}, 7^{\text {th }}$ and $8^{\text {th }}$ variables with high loading $(0.796,0.788$, and 0.590$)$, with Eigen value 1.896 that explained $12.643 \%$ of total variance.

Factor 3 named "Pension Scheme and Credit Access" contains following variables:

9 I have no liabilities to pay $\quad 0.821$

10 I have to enough credit access 0.746

11 I don't have any provision for pension scheme $\quad 0.642$

Eigen values $\quad 1.654$

Variance Explained $\quad 11.024 \%$

Factor 3 contains $9^{\text {th }}, 10^{\text {th }}$ and $11^{\text {th }}$ variables with high loading $(0.821,0.746$, and 0.642$)$ having Eigen value of 1.654 which explained $11.024 \%$ of total variance.

Factor 4 named "Facility for Old Age and Unemployment" contains following variables:

12 I have a chance for future unemployment 0.792

13 To have facility in old age $\quad 0.691$

Eigen values $\quad 1.198$

Variance Explained $\quad 7.985 \%$

Factor 4 contains $12^{\text {th }}$ and $13^{\text {th }}$ variables having high loading $(0.792$, and 0.691$)$ with Eigen value of 1.198 which explained $7.895 \%$ of total variance.

Factor 5 named "Saving Scheme and Remittance Access" contains following variables:

$\begin{array}{llc}14 & \text { I have suitable saving scheme } & 0.814 \\ 15 & \text { I have remittance access } & 0.661 \\ \text { Eigen values } & 1.043 \\ \text { Variance Explained } & 6.951 \%\end{array}$

Factor 5 contains $14^{\text {th }}$ and $15^{\text {th }}$ variable with high loading $(0.814$, and 0.661$)$, with eigenvalue of 1.043 which explained $6.951 \%$ of total variance.

In summary, Social Security with plan, Purchase and children Education, Pension Scheme and Credit Access, Facility for old age and Unemployment and Saving Scheme and Remittance Access these five factors can explain $63.208 \%$ of total variance.

\section{Research Model}

The researcher has found five factors that affect human saving propensity. Now the researcher has tried to know the significant impact of those factors on the propensity to save. So the analyst has decided to do the multiple regression analysis. The regression model is:

$Y=\alpha+\beta_{1} F_{1}+\beta_{2} F_{2}+\beta_{3} F_{3}+\beta_{4} F_{4}+\beta_{5} F_{5}+e$

Where,

$$
\mathrm{Y}=\text { Saving Propensity }
$$


This Saving Propensity can be affected by the following influencing factors of save:

$\mathrm{F}_{1}=$ Social Security with Plan

$\mathrm{F}_{2}=$ Purchase, and Children Education

$\mathrm{F}_{3}=$ Pension Scheme, and Credit Access

$\mathrm{F}_{4}=$ Facility for Old Age, and Unemployment

$\mathrm{F}_{5}=$ Saving Scheme, and Remittance Access

$\mathrm{e}=$ Error Term

And $\alpha$ is constant and $\beta_{1}, \beta_{2}, \beta_{3}, \beta_{4}$, and $\beta_{5}$, are the coefficients of an estimate.

Table No. 8: Regression Model Summary

\begin{tabular}{|c|c|c|c|c|}
\hline \multicolumn{5}{|c|}{ Model Summary(b) } \\
\hline Model & R & R Square & Adjusted R Square & Std. Error of the Estimate \\
\hline 1 & 0.490 & 0.240 & 0.224 & 0.98619 \\
\hline
\end{tabular}

a. Predictors: (Constant), REGR factor score 5 for analysis 1 , REGR factor score 4 for analysis 1, REGR factor score 3 for analysis 1, REGR factor score 2 for analysis 1 , REGR factor score 1 for analysis 1

b. Dependent Variable: Saving Intensity

Source: Author's Calculation (Based on Field Survey, 2016)

From table no. 8 , it is seen that there is a significant correlation between independent variables and dependent variables. At the level of $5 \%$ significant, the correlation is $49.0 \%$ which shows the moderate relation because the value of $\mathrm{R}$ is between 0.40 to 0.60 . The value of $\mathrm{R}^{2}$ indicates that $24 \%$ dependent variable can be explained by independent variables. Remaining $76 \%$ of the variance can be explained by the other variables.

Table No. 9: Analysis of Variance

\begin{tabular}{|c|c|c|c|c|c|c|}
\hline \multicolumn{7}{|c|}{ ANOVA(b) } \\
\hline Model & & Sum of Squares & df & Mean Square & F & Sig. \\
\hline \multirow{3}{*}{1} & Regression & 69.547 & 5 & 13.909 & 14.302 & 0.000 \\
\cline { 2 - 8 } & Residual & 219.802 & 226 & 0.973 & & \\
\cline { 2 - 8 } & Total & 289.349 & 231 & & & \\
\hline
\end{tabular}

a. Predictors: (Constant), REGR factor score 5 for analysis 1 , REGR factor score 4 for analysis 1 , REGR factor score 3 for analysis 1 , REGR factor score 2 for analysis 1 , REGR factor score 1 for analysis 1

b. Dependent Variable: Saving Intensity

Source: Author's Calculation (Based on Field Survey, 2016)

ANOVA output indicates that regression equation is explaining a statistically significant portion of the variability in the dependent variable from the variability of independent variables. This table also tells that the regression model is statistically significant ( $\mathrm{p}=0.000$ which is $\mathrm{p}<0.05)$. Another way, calculated F (14.302) value is greater than tabular (2.26) value. Thus it can be said that " $\mathrm{H}_{0}$ : There is no significant relationship between the causes of human saving behavior and saving propensity." is rejected and accept " $\mathrm{H}_{1}$ : There have significant relationships between the causes of human saving behavior and saving propensity." Hence ANOVA output supports the research hypothesis that there is a statistically significant relation between the set of independent variables and dependent variables.

\section{Test of Multi-Collinearity}

The researcher tries to know, whether there is any multi-collinearity problem in the regression model. So, it can be conducted through Collinearity Statistics. 
Table No. 10: Multi-Collinearity Test

\begin{tabular}{|c|cc|c|c|}
\hline Model & & \multicolumn{2}{|c|}{ Collinearity Statistics } \\
\hline 1 & & & Tolerance & VIF \\
\hline & REGR factor score 1 for analysis & 1 & 1.000 & 1.000 \\
\hline & REGR factor score 2 for analysis & 1 & 1.000 & 1.000 \\
\hline & REGR factor score 3 for analysis & 1 & 1.000 & 1.000 \\
\hline & REGR factor score 4 for analysis & 1 & 1.000 & 1.000 \\
\hline & REGR factor score 5 for analysis 1 & 1.000 & 1.000 \\
\hline
\end{tabular}

a Dependent Variable: Saving Intensity

Source: Author's Calculation (Based on Field Survey, 2016)

A VIF around 1 is very good (The Minitab Blog, 2016). So there has no any mulicollinearity problem in the model, and the model is good in shape.

\section{Parameter Estimates}

Table No. 11: Parameter estimates

\begin{tabular}{|c|c|c|c|c|c|c|}
\hline Model 1 & & \multicolumn{2}{|c|}{$\begin{array}{c}\text { Unstandardized } \\
\text { Coefficients }\end{array}$} & $\begin{array}{c}\text { Standardized } \\
\text { Coefficients }\end{array}$ & $\mathrm{t}$ & Sig. \\
\hline & & $\mathrm{B}$ & Std. Error & Beta & & \\
\hline & (Constant) & 3.793 & .065 & & 58.584 & .000 \\
\hline & REGR factor score 1 for analysis 1 & .051 & .065 & .045 & .779 & .437 \\
\hline & REGR factor score 2 for analysis 1 & .133 & .065 & .119 & 2.048 & .042 \\
\hline & REGR factor score 3 for analysis 1 & .516 & .065 & .461 & 7.954 & .000 \\
\hline & REGR factor score 4 for analysis 1 & .104 & .065 & .093 & 1.606 & .110 \\
\hline & REGR factor score 5 for analysis 1 & .060 & .065 & .054 & .924 & .357 \\
\hline
\end{tabular}

a. Dependent Variable: Saving Intensity

Source: Author's Calculation (Based on Field Survey, 2016)

Second column shows the predictor variables (constant, Factor 1, Factor 2, Factor 3, Factor 4, Factor 5,). The first variable represents the constant, also referred to intercept.

The third column shows the values for the regression equation for predicting the dependent variable from the independent variable. So, the regression equation is:

$Y=\alpha+\beta_{1} F_{1}+\beta_{2} F_{2}+\beta_{3} F_{3}+\beta_{4} F_{4}+\beta_{5} F_{5}+e$

This column provides the value for $\alpha, \beta_{1}, \beta_{2}, \beta_{3}, \beta_{4}$, and $\beta_{5}$ for the equation also.

Factor 1- The coefficient for Factor 1 is .051. So for every unit increase in Factor 1, a 0.051 unit increase in saving is predicted, holding all other variables constant.

Factor 2- The coefficient for Factor 2 is .133. So for every unit increase in Factor 2, a 0.133 unit increase in saving is predicted, holding all other variables constant.

Factor 3- The coefficient for Factor 3 is .516. So for every unit increase in Factor 3, a 0.516 unit increase in saving is predicted, holding all other variables constant.

Factor 4 - The coefficient for Factor 4 is .104. So for every unit increase in Factor 4, a 0.104 unit increase in saving is predicted, holding all other variables constant.

Factor 5- The coefficient for Factor 5 is .060 . So for every unit increase in Factor 5, a 0.060 unit increase in saving is predicted, holding all other variables constant.

The fourth column shows the values for the standard errors associated with the coefficients.

Finally, the research equation should be as follows:

Saving Propensity $=3.793+0.051\left(F_{1}\right)+0.133\left(F_{2}\right)+0.516\left(F_{3}\right)+0.104\left(F_{4}\right)+0.060\left(F_{5}\right)+e$ 


\section{CONCLUSION}

According to Mill's and Ricardo (1848), the rate of capital aggregation relies on the measure of the store from which sparing can be made and the quality of the mien to spare. Capital is the aftereffect of sparing, and funds originate from less present utilization for future merchandise. Ricardo (1917) concluded that capital amassing is the result of benefits since benefits prompt to sparing of riches which is utilized for capital development. Capital development relies on two variables, i.e., the ability to spare, and the will to spare. The ability to spare is more essential in the capital gathering. Rehman et al. (2011) regarded capital arrangement is the way to financial advancement, and capital development is conceivable through expanded saving money on the part of the general population.

So, it is clear that saving is one the most important factors for the developing country to be more developed. In this paper, the researcher has tried to find out the cause of the human saving behavior. The researcher has found a lot of variables that affect the propensity to save. But all variables are not applicable for everyone. For this reason, the researcher has taken only 15 variables. But these 15 variables are not enough because these variables explained only $24 \%$ variations. So there has a research gap. There should have been more variables to explain the cause of human saving. Here the researcher has found the main cause of human saving is that the having future security. So, financial institutions and the government should take some initiatives regarding these variables of savings. Financial institutions can open new policy (scheme) for security purpose and enhance interest rate. As a result, the people will save more than previous time. If the people save more, there will be more development.

\section{RefEREnCes}

Abid, S and Afridi, G.S. (2010). Assessing the Household Saving Pattern of Urban, and Rural Households in District Muzaffarabad, Pakistan Journal of Life and Social Sciences. 8(2). pp- 137-141.

Anastasiadou, S. D. (2011). Reliability and Validity Testing of A New Scale For Measuring Attitudes Toward Learning Statistics With Technology, Act a Didactic a Napocensia. 4. ISSN 2065-1430

Bendig, M., Giesbert, L. \& Steiner, S. (2009). Savings, Credit, and Insurance: Household Demand for formal financial services in Rural Ghana, BWPI Working Paper no 76, pp-1-26.

Cortina, J.M. (1993). What is coefficient alpha? An examination of theory and applications, Journal of Applied Psychology, 78, pp-98-104

Dell'Amore, G. (1983). Household Propensity to Save in Arnaldo Mauri (ed.), Mobilization of Household Savings, a Tool for Development, Finafrica, Milan.

Discover. (2016). Three Reasons to Save More Money, [online] Available: https://www.discover.com/online-banking/banking-topics/3-reasons-to-save-more-money/, [Accessed: November 15, 2016]

Fraczek, B. (2011). The factors affecting the level of household savings and their influence on economy development, 8th International scientific conference financial management of firms and financial institutions, Ostrava VŠB-TU Ostrava, Faculty of economics, finance department 6th - 7th September 2011

Horioka, Ch. \& Terada-Hagiwara, A. (2012). The determinants and long-term projections of saving rates in Developing Asia, Japan and the World Economy, 24 (2), pp-128-137.

Kaiser, H. F. (1960). The application of electronic computers to factors analysis. Educational and Psychological Measurement, 20, pp-141-151.

Kolasa, A. \& Liberda, B. (2014). Determinants of saving in Poland: Are they different than in other OECD countries? University of Warsaw, Faculty of Economic Science, Working Paper No. 13/2014 (130) 
Manyama, M. M. (2007). Instilling a Culture of Savings in South Africa. An M.Sc. Thesis Presented at Gordon Institute of Business Science, University of Pretoria, South Africa.

Mill's, J. \& Recardo, D. (1848). Principles of Political economy with some of their applications to social philosophy. Editions 1-7.

My Money Coach (2016), Ten reasons why you should save money, [online] Available: http://www.mymoneycoach.ca/saving-money/why-save-money, [Accessed: November 10, 2016]

Oxford Dictionaries. (2016). Propensity. [Online] Available: http://www.oxforddictionaries.com/definition/english/propensity; [Accessed: August10, 2016: 10.10PM]

Piggypot. (2016). The Top three Reasons to Save Money. [Online] Available: http:/ / piggypot.com/blog/the-top-3-reasons-to-save-money/. [Accessed: December 10, 2016]

Prinsloo, J.W. (2000). The Saving Behavior of the South African Economy. Occasional Paper No 14, South African Reserve Bank. South Africa.

Recardo, D. (1917). The principles of political economy and taxation. 3rd Edition.

Rehman. H., Bashir, F., \& Faridi. M. Z. (2011). Saving Behavior among Different Income Groups in Pakistan: A Micro Study, International Journal of Humanities and Social Science, 1(10).

The Balance. (2016). Seven reason for saving. [Online] Available: https://www.thebalance.com/learn-the-most-important-reasons-to-save-money-2386123, [Accessed: December 10, 2016]

The Extra Income Project. (2016). Seven Best Reasons You Should Save Money. [Online] Available: http:/ /theextraincomeproject.com/7-essential-reasons-save-money/. [Accessed: November 15, 2016]

The Minitab Blog. (2016). VIF [online], Available: http://blog.minitab.com/blog/starting-out-withstatistical-software/what-in-the-world-is-a-vif. [Accessed: August10, 2016: 10.00PM]

Wikipedia. (2016). Propensity. AOnline] Available: https://en.wikipedia.org/wiki/Marginal_propensity_to_save. [Accessed: August10, 2016: 10.15 PM]

Yong, G. A., \& Pearce, S. (2013). A Beginner's Guide to Factor Analysis: Focusing on Exploratory Factor Analysis, Tutorials in Quantitative Methods for Psychology, 9(2), pp-79-94.

Publish Online and Print Version Both

ISSN Online: 2312-203X 